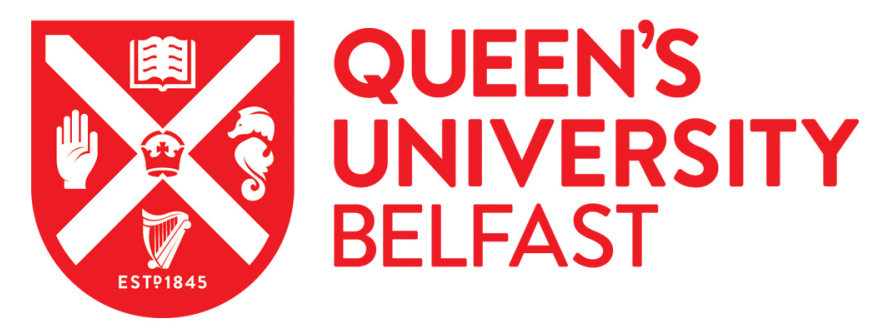

\title{
Influence of waves and currents on the growth rate of the kelp Laminaria digitata (Phaeophyceae)
}

Millar, R., Houghton, J., Elsaesser, B., Mensink, P., \& Kregting, L. (2019). Influence of waves and currents on the growth rate of the kelp Laminaria digitata (Phaeophyceae). Journal Of Phycology.

https://doi.org/10.1111/jpy.12943

Published in:

Journal Of Phycology

Document Version:

Peer reviewed version

Queen's University Belfast - Research Portal:

Link to publication record in Queen's University Belfast Research Portal

Publisher rights

(c) 2019 Phycological Society of America. This work is made available online in accordance with the publisher's policies. Please refer to any applicable terms of use of the publisher.

\section{General rights}

Copyright for the publications made accessible via the Queen's University Belfast Research Portal is retained by the author(s) and / or other copyright owners and it is a condition of accessing these publications that users recognise and abide by the legal requirements associated with these rights.

Take down policy

The Research Portal is Queen's institutional repository that provides access to Queen's research output. Every effort has been made to ensure that content in the Research Portal does not infringe any person's rights, or applicable UK laws. If you discover content in the Research Portal that you believe breaches copyright or violates any law, please contact openaccess@qub.ac.uk. 
MISS RACHEL MILLAR (Orcid ID : 0000-0002-1849-7946)

Article type : Regular Article

Influence of waves and currents on the growth rate of the kelp Laminaria digitata

(Phaeophyceae) $)^{1}$

Rachel Millar ${ }^{2}$

School of Natural and Built Environment, Queen's University Belfast, David Keir Building, Queen's University, Belfast, BT7 1NN, UK

Jonathan Houghton

School of Biological Science, Queen's University Belfast, 19 Chlorine Gardens, Belfast, BT9 5DL, UK

\section{Björn Elsäßer}

Danish Hydraulics Institute (DHI), Ports and Offshore Technology, Agern Allé 5, 2970 Hørsholm, Denmark

Paul Mensink

Centre for Environment and Sustainability, Western University, 1151 Richmond St, London, ON, N6A 3K7, Canada

School of Biological Science \& Institute of Global Food Security, Queen's University Belfast, 97 Lisburn Road, Belfast, BT9 7BL, UK

This article has been accepted for publication and undergone full peer review but has not been through the copyediting, typesetting, pagination and proofreading process, which may lead to differences between this version and the Version of Record. Please cite this article as doi: 10.1111/jpy.12943-18-194

This article is protected by copyright. All rights reserved 


\section{Louise Kregting}

School of Natural and Built Environment, Queen's University Marine Laboratory, 12-13 The Strand, Portaferry, BT22 1PF, UK

${ }^{2}$ Author for correspondence: email rmillar728@qub.ac.uk

Editorial Responsibility: T. Wernberg (Associate Editor)

Running Title: Influence of waves and currents on kelp growth

\section{Abstract}

The kelp Laminaria digitata grows in the low intertidal region along energetic coastlines exposed to a range of hydrodynamic environments. Macroalgae in the intertidal zone can experience both waves and currents independently, but it is unknown how they influence growth rate. Relative growth rate of the meristematic region and the entire blade of $L$. digitata were measured to assess the influence of wave and current motion from three hydrodynamic environments; low current and low wave (LCLW), high current and low wave (HCLW) and high wave and low current (HWLC). Alongside hydrodynamic data, seawater nutrient concentrations and temperature were also collected and analysed. Results suggest that differences in $L$. digitata relative growth rates were not attributed to the seawater nutrient concentrations or temperature but to the hydrodynamic environments. At the high current condition, kelp growth rate of the meristematic region was enhanced by $45 \%$ compared to the high wave condition. When including the entire blade growth rate, an average increase of $25 \%$ was observed between the high current and high wave condition. Potentially, the division in growth rate observed between the wave and current motion is related to the frequency and magnitude at which the hydrodynamic forces act. These findings highlight the complexity of the hydrodynamic environment and that forces associated with waves and currents may have a significant role on the productivity of kelp.

Keywords: Macroalgae, Phaeophyceae, growth, production, water motion, nutrients, macroalgae, hydrodynamics 
Abbreviations: relative growth rate, RGR; meristematic relative growth rate, MRGR and blade relative growth rate, BRGR; low current \& low wave, LCLW; high current \& low wave, HCLW; high wave \& low current, HWLC; acoustic wave and current profiler, AWAC; acoustic doppler current profiler, ADCP; linear mixed model, LMM; akaike information criterion, AIC

\section{INTRODUCTION}

Kelp forests are described as some of the most productive marine habitats in the world supporting a diverse range of flora and fauna (Dayton 1985, Duggins et al. 1989, Graham 2004, Reed et al. 2011). Macroalgae are found in the intertidal and subtidal regions globally experiencing a range of physical disturbances from both wave and current hydrodynamics (Kregting et al. 2016). While light and nutrients are essential drivers of kelp growth (e.g., Hanisak 1983, Falkowski and Raven 1997), water motion is also well documented as a key parameter influencing morphology and physiological processes of macroalgae (Kregting et al. 2008, Hurd et al. 2014, Hurd 2017). Further, exposure to hydrodynamic disturbance is identified as a controlling factor in the distribution and composition of intertidal and subtidal macroalgal communities (Sousa 1985, Burrows 2012). Disentangling the complex interaction between the environmental parameters, light, temperature and nutrients as well as hydrodynamics, that all influence macroalgae growth, can be difficult. Adding to the complexity, water motion influences essential growth variables such as the underwater light climate due to turbidity of the water via resuspension of sediment and the rate of nutrient delivery through the process of mass-transfer limitation (Hurd 2000).

Of the few direct growth rate measurements of kelp species in relation to water motion in the field including Saccharina longicruris (Gerard and Mann 1979), Macrocystis pyrifera (Hepburn et al. 2007), Laminaria hyperborea (Kregting et al. 2013) and Laminaria digitata (Kregting et al. 2016), results showed that the kelps had variable responses to this physical driver. The differences observed between these studies on the effect of hydrodynamics on growth rate may arise as a direct result of physicality from the motion (e.g., elongation/ thickness of blades) and indirect effects arising from the hydrodynamics altering the surrounding environment of kelp (e.g., light and mass-transfer limitation of nutrients). For example, Gerard and Mann (1979) attributed increased productivity of $S$. longicruris at the wave sheltered site versus the wave exposed site to a higher nitrogen source at the sheltered site. Hepburn et al. (2007) attributed the positive increase in 
growth of $M$. pyrifera with increased wave activity owing to the heightened availability of nutrients to the kelp but only in autumn. While Kregting et al. (2016) found variation in growth rate of $L$. digitata was influenced strongly by water motion (waves or currents), there was no relationship to essential growth parameters such as light, temperature and seawater nutrients. The authors hypothesised that lower growth rates at the high wave and high current site for L. digitata was owing to a trade-off of investing their energy into increased structural tissue rather than blade elongation.

Kregting et al. (2016) did not specifically separate how the 'type' of water motion (wave vs. current) influences growth rate of Laminaria digitata. For kelp, the forces associated with shallow water waves and tidally driven currents both apply cyclic forces on the thallus, yet the impact of forcing may differ due to significantly varied frequency of oscillation, magnitude and direction (Denny and Gaylord 2002, Gaylord et al. 2007). Tidal current flows are driven by the gravitational pull of celestial bodies and the localised result is a flow of fluid which is oscillatory in nature and as such may be considered as a wave, albeit with a significantly longer oscillatory period, typically in the range of $12-24 \mathrm{~h}$. Thus, applied hydrodynamic loading tends to be persistent with similar loading conditions experienced over relatively long periods of time. In contrast, near- or far-field wind generated waves typically result in fluid motions with an oscillatory frequency in the order of seconds, resulting in hydrodynamic loads of correspondingly increased frequencies of oscillation. Furthermore, hydrodynamic forces and blade acceleration in wave environments may far exceed those experienced in typical tidal environments. Stevens et al. (2002) found waves in the order of $0.5 \mathrm{~m}$ high, resulted in blade speed acceleration exceeding $30 \mathrm{~m} \cdot \mathrm{s}^{-1}$ and force on the stipe of approximately $300 \mathrm{~N}$. This leads to extreme wave loading on the thallus as it is entrained in a sharply oscillating flow with the horizontal velocity of successive waves creating intense snagging action at high frequency. Disentangling how predominantly wave or predominantly current environments directly influence growth rate of kelp is yet to be explored.

Laminaria digitata is an ideal candidate species to tease apart the influence of waves or currents on growth and productivity as it can be found in a range of hydrodynamic environments. To investigate this, the growth rates were determined in the meristematic region and for the overall growth rate of the blade to incorporate the effect of blade length on growth (Niklas and Enquist 2001). These growth rates of L. digitata were measured at three areas including a low wave and low current area, a low wave and high current area and a high wave and low current area. To control for variations in seawater nutrients and temperature, sites were chosen in close proximity 
to one another, temperature and seawater nutrients were also measured to ensure that the only key parameter varying significantly were the hydrodynamics.

\section{MATERIALS AND METHODS}

Study sites

Strangford Lough in Northern Ireland is the largest sea inlet in the United Kingdom where a range of wave and current locations can be found (Kregting and Elsäßer 2014; Fig. 1). Numerous Islands within the Lough create complex hydrodynamic areas so that low current flow $\left(<0.4 \mathrm{~m} \cdot \mathrm{s}^{-1}\right)$ can be found within the basin as well as high current flows of $\sim 3.5 \mathrm{~m} \cdot \mathrm{s}^{-1}$ within the $8-\mathrm{km}$ channel entrance, known as the Narrows. All sites within the Lough are restricted from the influence of wave activity from the open sea (Kregting and Elsäßer 2014) with a tidal range between $2-4 \mathrm{~m}$. On either side of the outer entrance of the Lough are rocky shores which experience wind and swell waves generated in the Irish Sea resulting in significant wave heights ( $\mathrm{Hm} 0)$ of $4 \mathrm{~m}$ or higher (Kregting et al. 2013). To select areas with the required hydrodynamic conditions prior to measuring growth of Laminaria digitata, wave and tidal data were extracted from numerical models developed by Kregting et al. $(2014,2016)$. Using the extracted data, three areas with different hydrodynamic environments were chosen, i) a low wave and low current area with benign hydrodynamics of low wave $(\sim 0.15 \mathrm{~m})$ and low currents $\left(\sim 0.12 \mathrm{~m} \cdot \mathrm{s}^{-1}\right)$, ii) a high current area with low wave and iii) a high wave area with low current (Fig. 1). Within each area, three five replicate sites for each hydrodynamic condition were selected (Fig. 1, Table 1). Preferably a high wave and high current scenario would have been included into the study but finding multiple replicate sites with a similar hydrodynamic environment proved difficult. In the Narrows and along the open coastal shores, kelp were located on hard rocky substrates, whereas in the low wave and low current site, large boulders provided the suitable substrate for the kelp to grow.

\section{Classification of hydrodynamic condition}

To quantify and validate that each selected area adhered to the initial numerically predicted characteristics of a 'high or low wave' and 'high or low current' site, Acoustic Doppler Current Profilers (ADCPs) were deployed to measure significant wave height $(\mathrm{Hm} 0)$ and current velocities $\left(\mathrm{m} \cdot \mathrm{s}^{-1}\right)$ during January to February 2017 . The three ADCP's make and models used were a 
Nortek Acoustic Wave and Current profiler (AWAC) and two Nortek Aquadopps. At the high wave area, the AWAC ADCP was deployed at a mean low water $10 \mathrm{~m} \sim 0.3 \mathrm{~km}$ out from the coastline to encapsulate the incoming waves from the Irish Sea that each site would experience. At both low wave areas, the two Aquadopps were deployed (MLW depth of $2 \mathrm{~m}$ ). Sampling configurations for each instrument were similar (see Table 2). ADCP preparation prior to deployment involved the checking of internal sensors and the calibration of the internal compass which were carried out as described in Elsäßer et al. (2016). The ADCPs were deployed using SCUBA at each area that represented the three conditions; Killyleagh (LCLW), Cloughy Rock (HCLW) and Kearney (HWLC; Table 1). The instruments were orientated in their frames so that their designated major axes were to the north cardinal direction and they were positioned level to ensure that the beam tilt was no more than $25^{\circ}$ which would render the data collected from each instrument inaccurate. Hydrodynamic data (waves and currents) from the three ADCP's were post-processed using the built-in processing settings of Storm software version 1.16.01. All data were offset to incorporate the mounting height of the ADCPs in each frame of $0.5 \mathrm{~m}$ for the AWAC and $0.2 \mathrm{~m}$ for the Aquadopps.

\section{Growth measurements}

The relative growth rate of Laminaria digitata blade tissue was recorded in the meristematic region where maximum growth occurs and to incorporate the potential influence of the size of the blade, the growth rate along the length of the longest blade was also measured. To determine the meristematic relative growth rate (MRGR) and the overall blade relative growth rate (BRGR) of $L$. digitata seasonally at the various hydrodynamic regimes selected, measurements were carried out during February to March 2016 (Winter), July to August 2016 (Summer) and January to February 2017 (Winter). At each site, L. digitata thalli $(\mathrm{n}=15-20)$ with blade lengths $>0.3 \mathrm{~m}$ were haphazardly chosen at low water as close to the water line as feasible. Individual kelp were tagged with cattle tags using cable ties for identification at the base of the stipes. To measure the meristematic growth an initial hole was punched (diameter of hole $0.7 \mathrm{~cm}$ ) $\sim 5 \mathrm{~cm}$ from the stipe/laminar junction in the meristematic region and measured to the nearest $\pm 0.5 \mathrm{~cm}$ on the longest blade (Parke 1948). On the same blade a further 3 - 5 holes were punched, spaced out and measured along the length of the blade to calculate the overall growth of the blade tissue (BRGR). Blade lengths across the sites ranged from $\sim 0.3 \mathrm{~m}$ to $\sim 3 \mathrm{~m}$. Approximately $30 \mathrm{~d}$ after the initial 
measurements were recorded, the tagged kelp were removed and brought back to the laboratory for final measurements. Relative growth rate (RGR, $\left.d^{-1}\right)$ was calculated using the Evans (1972) equation modified by Stephens and Hepburn (2016).

\section{Seawater nutrient concentrations}

While the sites were relatively close in proximity to each other, seawater nutrient concentration (nitrate and phosphate) were measured in situ to account for differences in growth rate that may be caused by differences in nutrient concentrations amongst the sites. Three replicate $60 \mathrm{~mL}$ seawater samples were collected in acid washed sample bottles at each site at the start and end of the growth study period, taken at low water $(0.5 \mathrm{~m}$ depth or below). All samples were filtered through Whatman $\mathrm{GF} / \mathrm{C}$ glass-fibre filters and frozen at $-20^{\circ} \mathrm{C}$ for later analysis of nitrate $\left(\mathrm{NO}_{3}{ }^{-}\right)$and phosphate $\left(\mathrm{PO}_{4}{ }^{3-}\right)$ seawater concentrations using a Bran+Luebbe AutoAnalyzer 3.

\section{Environmental parameters}

While irradiance is an important variable for seasonal variation in growth, Kregting et al. (2013, 2016) found no significant differences in irradiance levels across various similar sampling locations in and around Strangford Lough to this study. Therefore, it was assumed that irradiance levels from our sites would have only minimal differences owing to their proximity and therefore no further investigation was carried out. With regards to temperature, sensors (Dataflow Systems Pty Ltd., Christchurch, New Zealand and Gemini Data Loggers Ltd., Chichester, UK) were attached to concrete blocks at all sites apart from those at Killard 1 and 2, where eyelet bolts were drilled into the rock face and loggers were attached with cable ties. Temperature levels $\left({ }^{\circ} \mathrm{C}\right)$ were recorded over a 10-minute scan period.

\section{Statistical Analysis}

To determine differences between the hydrodynamics and temperature data a bootstrap resampling method (MATLAB and Statistics Toolbox Release 2018a The MathWorks, Inc., Natick, MA, 
United States) was used to calculate the mean and confidence interval for the significant wave height (Hm0; 1000 resamples) and current velocity $\left(\mathrm{m}^{\cdot} \mathrm{s}^{-1} ; 1000\right.$ resamples) from each ADCP and temperature $\left({ }^{\circ} \mathrm{C}\right)$ from each logger (1000 resamples).

A regression analysis was carried out to examine the relationship between the response variable, relative growth rate (RGR; meristematic region model and overall blade model) and the explanatory variables: hydrodynamic condition (wave and current), seawater nitrate and phosphate concentration. To analyse the differences in relative growth rate, we constructed a linear mixed model (LMM) adding site as a random effect to account for the correlation between the kelp taken from the same site. Season was also included in the model as a random effect to account for any variation caused by season. Continuous input variables of nitrate and phosphate concentrations were scaled (mean set to zero and standardised by the standard deviation) to improve interpretability of the regression coefficients. Akaike information criterion (AIC) values were used for selecting the best fitting model (Akaike 1973). Model assumptions were tested by extracting residuals from the LMM and examining the residual plots. The RGR response variable required square root transformation for normality. The LMM was constructed in R (R Core Team 2018) using the lme4 package (Bates et al. 2015).

\section{RESULTS}

\section{Classification of hydrodynamic condition}

Based on the period of $17 / 1 / 17$ to $13 / 2 / 17$, significant wave height $(\mathrm{Hm} 0)$ differed between the ADCP deployment locations (Killyleagh $=0.1457$ CI 0.1253 and $0.1662 \mathrm{~m}$; Cloughy Rock $=$ 0.0933 CI 0.0842 and $0.1023 \mathrm{~m}$; Kearney $=0.7933$ CI 0.7378 and $0.8488 \mathrm{~m}$ ). Significantly larger waves were observed at Kearney (Irish Sea) with up to a 5.4-fold difference in significant wave height than Killyleagh and 8.5-fold difference compared to the wave height at the Cloughy Rock site (Fig. 2).

Likewise, current velocity was statistically different between all ADCP deployment locations (Killyleagh $=0.1196$ CI 0.1170 and $0.1222 \mathrm{~m} \cdot \mathrm{s}^{-1}$; Cloughy Rock $=0.3364$ CI 0.3257 and $0.3478 \mathrm{~m} \cdot \mathrm{s}^{-1} ;$ Kearney $=0.0753 \mathrm{CI} 0.0744$ and $\left.0.0763 \mathrm{~m} \cdot \mathrm{s}^{-1}\right)$. Maximum velocities of 1.19 $\mathrm{m} \cdot \mathrm{s}^{-1}$ were recorded at Cloughy Rock which was a 2.5 -fold higher maximum velocity than Killyleagh of $0.47 \mathrm{~m} \cdot \mathrm{s}^{-1}$ (Fig. 2). 
Temperature levels

In winter 2016 based on the recording period of $27 / 2 / 16$ to $20 / 3 / 16$, temperature recorded at the LCLW condition $(\mathrm{n}=3)$ was on average $8.06^{\circ} \mathrm{C}\left(\mathrm{CI} 8.02\right.$ and $\left.8.11^{\circ} \mathrm{C}\right)$, HCLW condition $(\mathrm{n}=4)$ $7.82^{\circ} \mathrm{C}\left(\mathrm{CI} 7.75\right.$ and $\left.7.87^{\circ} \mathrm{C}\right)$ and HWLC condition $(\mathrm{n}=3) 8.06^{\circ} \mathrm{C}\left(\mathrm{CI} 8.03\right.$ and $\left.8.08^{\circ} \mathrm{C}\right)$.

Temperatures were higher in summer 2016 based on the period 25/7/16 to 16/8/16 and averaged in the LCLW condition $(\mathrm{n}=2) 14.52^{\circ} \mathrm{C}\left(\mathrm{CI} 14.49\right.$ and $\left.14.55^{\circ} \mathrm{C}\right), \mathrm{HCLW}$ condition $(\mathrm{n}=$ 3) $13.93^{\circ} \mathrm{C}\left(\mathrm{CI} 13.89\right.$ and $\left.13.97^{\circ} \mathrm{C}\right)$ and at the HWLC condition $(\mathrm{n}=2) 13.8^{\circ} \mathrm{C}(\mathrm{CI} 13.78$ and $\left.13.82^{\circ} \mathrm{C}\right)$. Although an important and essential parameter for kelp growth, temperature could not be added into the models due to equipment loss.

\section{Seawater nutrient concentrations}

No relationship was observed between seawater nitrate concentrations and growth rates, the average nitrate concentrations were $\sim 2.9 \mu \mathrm{M}$ in winter and $\sim 0.9 \mu \mathrm{M}$ in summer. Similarly, a nonsignificant relationship was also observed between seawater phosphate levels and growth rate with average phosphate concentrations in winter of $\sim 0.5 \mu \mathrm{M}$ and $\sim 0.1 \mu \mathrm{M}$ in summer. Removal of both seawater nitrate and phosphate concentration one at a time and removal of both together from the equation improved the model results as evaluated by the AIC values (Tables 3 and 4).

\section{Growth measurements}

The highest relative growth rates (MRGR and BRGR) of Laminaria digitata occurred typically within the HCLW condition. Although in winter 2016 the highest growth rate was found in the LCLW condition and differed from both summer 2016 and winter 2017, this is echoed in both MRGR and BRGR (Figs. 3, 4). Lowest relative growth rates (MRGR and BRGR) were observed at the HWLC condition throughout each sampling season (Figs. 3, 4). Seasonal variation was also observed and anticipated showing lower growth rate in summer 2016 compared to winter 2016 and 2017 sampling periods (Figs. 3, 4). 
The results from the LMMs examining the relationship between the response variable, relative growth rate (RGR) and the explanatory variables; waves, currents, seawater nitrate and phosphate suggests that hydrodynamic conditions are driving the growth rate of Laminaria digitata. With the HWLC condition leading to a lower relative growth rate observed compared to that of the LCLW condition ( $p<0.001$; Table 3 and $p<0.001$; Table 4). Meristematic RGR was $17 \%$ higher at HCLW compared to LCLW ( $p<0.001$; Table 3$)$ whereas RGR at HWLC was $28 \%$ lower than LCLW $(p<0.001$; Table 3$)$. When overall blade relative growth rate was taken into account, a significant difference was observed between the LCLW and HWLC with the HWLC condition growth rate being 30\% lower than LCLW ( $p<0.001$; Table 4). However, the two current sites were not significantly different with only a 5\% difference between the HCLW and LCLW conditions.

\section{DISCUSSION}

It is well established that macroalgal growth and productivity is influenced by complex interactions between multiple environmental parameters (Hanisak 1983, Wheeler 1988, Falkowski and Raven 1997, Hurd 2000). In this study, the influencing variable that best explained the difference in Laminaria digitata growth rates was the hydrodynamic conditions. Compared to previous investigations, this study also assessed the nature of the hydrodynamics influencing growth rate of kelp by specifically looking at the effect of either wave or current motion. Our results demonstrated that as significant wave height $(\mathrm{Hm} 0)$ increased (Fig. 2) the observed growth rate was on average $28 \%$ lower in the meristematic region of L. digitata for the HWLC condition compared to the LCLW condition. Similar results were observed when the overall blade relative growth rate was considered, on average growth rate here was $30 \%$ lower as wave conditions increased from the benign LCLW to HWLC condition. The meristematic growth rate of L. digitata was on average $17 \%$ higher at the HCLW condition than the LCLW condition (increased current velocity; $\mathrm{m} \cdot \mathrm{s}^{-1}$ ), however, when considering the overall blade growth rate, it was $5 \%$ lower. Therefore, using the meristematic growth region and overall blade growth rate we observed a $45 \%$ and $25 \%$ difference respectively in growth between the wave dominated and current dominated sites. Assessing how different hydrodynamic conditions influence growth rates of kelp highlights the importance of including the size of an organism into the growth analysis. Differences between sites when overall blade growth rates were used were less pronounced than if the meristematic 
growth rates were used. Ideally a high current/high wave scenario would have also been sampled, but it was not possible to find replicate sites with these extreme characteristics. We can only hypothesise that kelp growth rate may be even lower than the observed sites sampled in this study and if possible, warrants future investigation. Regardless, the results illustrated that waves and currents influence the growth rate of the kelp L. digitata.

An allometric relationship was detailed in plants by Niklas and Enquist (2001) between annualized growth rates and body length using a $3 / 4$ scaling exponent thus concluding that the size can affect the growth rate. We emphasise that Laminaria digitata morphology varies as expected across hydrodynamic environments. However, while Gerard (1987) observed that Laminaria saccharina in the laboratory displayed higher elongation rates when longitudinal tension from weights as a proxy for water motion was applied, our findings do not fully support these results, that kelp morphology may be influenced by water motion without affecting the productivity. Blade length was shortest $(\sim 0.61 \mathrm{~m})$ and narrowest at the HWLC sites coinciding with a significantly lower growth rate (measured as elongation) compared to the HCLW sites which had longer blade lengths of $\sim 1.31 \mathrm{~m}$ with wider blades (R. Millar, pers. obs.). These results also do not fit with Niklas and Enquist (2001) allometric scaling idea. Although, the kelp located in the HCLW condition have the highest meristematic growth rate, which may be explained by the constant longitudinal force associated with a high current flow environment as observed in laboratory grown kelp (Gerard 1987). When considering the overall blade growth rate, no significant difference was observed between the growth rates at the HCLW condition and at the LCLW condition despite the increased current velocity in the HCLW condition. These results suggest that longer blade length or the narrowing of blades (streamlining), does not always promote an increase in growth or elongation rate compared to shorter and wider blades and that other factors may also come into play.

Overall these results prompt the authors to hypothesise that the mechanism for altered growth rate within kelp is potentially due to the differences between the frequency of hydrodynamic forces. The frequency of the forces and snagging action (kelp stretched to full elongation) associated with both wave and current motion can be relatively brief in a wave dominated environment (s) compared to that in a tidally driven current environment where the forces occur over longer periods (h). Bekkby et al. (2014) suggested that wave exposure had a stronger effect as a stressor on kelp compared to that of regular bi-directional stress caused by current flow. The hydrodynamic forces associated with wave environments are more frequent and 
potentially create additional loading and fatigue stresses on the blade/thallus than less frequent loading in current hydrodynamics with the possible result that there are trade-offs in growth strategies.

Two growth strategies to avoid breakage in algae were suggested by Martone (2007): an increase in cross-sectional area (thickness) and to increase tissue strength. This second growth strategy trade-off was also suggested by Kregting et al. (2016), proposing that kelp in wave environments allocate energy into tissue strength to avoid damage/breakage. Martone (2007) observed higher breaking stress in older segments of the red algae Calliarthron tuberculosum compared to younger segments which was due to the thickening of cell walls. Similarly, increased blade thickness in numerous red algae species arose due to the addition of medullary tissue, resulting in a greater force to break (Demes et al. 2011). Our observations found that there was a thickening of average blade tissue of Laminaria digitata in LCLW from $0.52 \mathrm{~mm}$ to $0.77 \mathrm{~mm}$ in the HWLC condition (R. Millar, unpub. data). Although this mechanism is yet to be explored in detail to explain strength differences in kelp (Krumhansl et al. 2015), our findings do support the idea that there could be a trade-off between investing energy in reinforcement as opposed to growth rate and elongation (Kregting et al. 2016), in order to reduce blade damage as a result of hydrodynamic force impinged on L. digitata. These trade-off strategies suggested above, infer a shift in energy allocation from growth to either the overall thickening of tissue or strengthening of particularly tissue layers/cells, which may in turn, influence the physiological processes of kelp.

A physiological trade-off strategy was suggested by Sakanishi et al. (2017) between productivity and thallus toughness in Laminariales. This is due to an observed significant positive correlation between the thallus mass per area (TMA) and force to penetrate the thallus (toughness) and a significant negative correlation between photosynthetic nitrogen-use efficiency with the TMA. We observed that blade thickness increased with both the increase in wave height and current velocity (R. Millar, unpub. data), therefore Laminaria digitata blades may become tougher and in turn have a lower productivity in the form of photosynthetic capacity per area biomass at the high wave and high current sites supporting Sakanishi et al. (2017) physiological trade-off strategy. However, Mass et al. (2010) observed in the red alga Gracilaria cornea that an increase in flow speed significantly boosted the photosynthetic rate and considerably reduced the oxygen concentration within the organism. Kraemer and Chapman (1991) found that carbon uptake was stimulated by a static tensile force in juvenile Egregia menziesii and facilitated morphological adaptions due to photosynthetic carbon partitioning into the cell wall synthesis. With higher 
growth rates in L. digitata observed within the current environment owing to the associated forces occurring over an extended period of time, this may be stimulating carbon uptake and increased removal of oxygen and in turn creating higher growth rate than kelp exposed to short burst period of forces from wave exposure and therefore lower growth rates.

Hydrodynamic conditions directly play a role on the supply of nutrients and removal of metabolic by-products by influencing the thickness of the diffusion boundary layer (DBL) at the blade surface (Wheeler 1980, Hurd 2000, Mass et al. 2010) and therefore influencing growth rate. For some macroalgal species mass-transfer limitation in regard to dissolved nutrients, has been noted in the subtidal environment under low unidirectional flow velocities $\left(<0.06 \mathrm{~m} \cdot \mathrm{s}^{-1}\right)$ the movement of molecules to and from the blade surface is limited by flow (Kregting et al. 2008, 2015). As Laminaria digitata is an intertidal species it would be expected that mass-transfer limitation could occur at low tides, which all sites would experience, especially during calm weather conditions. We do not have flow velocities recorded from the precise locations where $L$. digitata were measured in the intertidal zone, nonetheless, it is unlikely that mass-transfer limitation was driving the observed differences in growth rates between the current and wave sites otherwise it would be expected that the lowest current site would have a lower growth rate than the wave site. Further, while nitrate and phosphate seawater concentrations were included into the linear mixed model (LMM), these environmental parameters did not explain the differences in growth rate to the same level as the hydrodynamic conditions tested. For many macroalgal species, seawater nitrate concentrations drive seasonal growth patterns with the result that a higher growth rate may be observed in late winter followed by a reduced growth phase in the summer as seawater nitrate concentration decreases (Chapman and Craigie 1977, 1978, Gagné et al. 1982). Environmental temperature (air and seawater) is also seasonal, and while it was not added specifically to the models, temperature is indirectly considered in the form of season as a random effect in the models. This seasonal growth pattern has been observed for L. digitata (Schaffelke and Luning 1994) and was clearly demonstrated in this study (Figs. 3, 4).

There are few studies directly investigating growth rate of kelps with hydrodynamics in the field and the results are difficult to disentangle. For example, the findings in this study contrast that of Hepburn et al. (2007) where increased growth rate of the kelp Macrocystis pyrifera was due to wave action enhancing nutrient availability. Likewise, the study by Gerard and Mann (1979) could not relate differences in growth rate of Saccharina longicruris directly to water motion as the driver of increased growth rate was because of a higher nitrogen availability from 
bryozoans at the wave sheltered site. Interestingly, Kregting et al. (2013) observed that water motion did not have a direct influence on the growth rate of Laminaria hyperborea between wave exposed and wave sheltered sites. Our observations concur with Kregting et al. (2016) where the direct influencing factor on the growth rate of $L$. digitata was water motion. These studies show that the influence of environmental parameters such as hydrodynamics and nitrogen driving growth in kelp are complex and that physical and physiological processes play an integral role in the growth strategy for different species.

Highly productive kelp forests could experience a marked shift in hydrodynamic environments as future wave climate estimates predict a change by the end of the 21 st century with increased wave height and storm frequency as forecast (Grabemann and Weisse 2008, Rhein et al. 2013, Castelle et al. 2018). With an average relative growth rate difference of $25-45 \%$ between wave and current hydrodynamic environments this could have implications on productivity and blue carbon estimates, as carbon represents $\sim 30 \%$ dry weight of kelp tissue (Mann, 1972, Kregting et al. 2016, Smale et al. 2016). The uncertainty of productivity surrounding this important marine habitat particularly with forecasted changes in wave climate, requires further investigation into the mechanism driving the observed difference between wave and current hydrodynamic environments in Laminaria digitata growth rates.

\section{ACKNOWLEDGEMENTS}

We would like to thank S. Exley, A. Flaherty, P. Joyce, P. Schmitt, J. Rogers and S. Rogers of Cuan Marine Services Ltd., for providing field assistance and technical support. We also thank G. Savidge and P. Lamont-Kane for providing invaluable comments and feedback on this manuscript. The work undertaken has been supported by Engineering and Physical Sciences Research Council EPSRC (PID: M120403C).

\section{REFERENCES}

Akaike, H. 1973. Maximum likelihood identification of Gaussian autoregressive moving average models. Biometrika. 60:255-65. 
Bates, D., Mächler, M., Bolker, B. \& Walker, S. 2015. Fitting linear mixed-effects models using lme4. J. Stat. Soft. 67:1-48.

Bekkby, T., Rinde, E., Gundersen, H., Norderhaug, K.M., Gitmark, J.K. \& Christie, H. 2014. Length, strength and water flow: relative importance of wave and current exposure on morphology in kelp Laminaria hyperborea. Mar. Ecol. Prog. Ser. 506:61-70.

Burrows, M.T. 2012. Influences of wave fetch, tidal flow and ocean colour on subtidal rocky communities. Mar. Ecol. Prog. Ser. 445:193-207.

Castelle, B., Dodet, G., Masselink, G. \& Scott, T. 2018. Increased winter-mean wave height, variability, and periodicity in the Northeast Atlantic over 1949-2017. Geophys. Res. Lett. 45:3586-96.

Chapman, A.R.O. \& Craigie, J.S. 1977. Seasonal growth in Laminaria longicruris: relations with dissolved inorganic nutrients and internal reserves of nitrogen. Mar. Biol. 40:197-205.

Chapman, A.R.O. \& Craigie, J.S. 1978. Seasonal growth in Laminaria longicuris: relations with reserve carbohydrate storage and production. Mar. Biol. 46:209-13.

Dayton, P.K. 1985. Ecology of kelp communities. Annu. Rev. Ecol. Syst. 16:215-45.

Demes, K.W., Carrington, E., Gosline, J. \& Martone, P.T. 2011. Variation in anatomical and material properties explains differences in hydrodynamic performances of foliose red macroalgae (Rhodophyta). J. Phycol. 47:1360-7.

Denny, M. \& Gaylord, B. 2002. The mechanics of wave-swept algae. J. Exp. Biol. 205:135562.

Duggins, D.O., Simenstad, C.A. \& Estes, J.A. 1989. Magnification of secondary production by kelp detritus in coastal marine ecosystems. Science 245:170-3. 
Elsaesser, B., Torrens-Spence, H., Schmitt, P. \& Kregting, L. 2016. Comparison of four acoustic doppler current profilers in a high flow tidal environment. In Proceedings of the 3rd AWTEC 2016 Asian Wave and Tidal Energy Conference (AWTEC 2016). AWTEC, 3rd Asian Wave and Tidal Energy Conference, Singapore, Singapore, 24/10/2016.

Evans, G.C. 1972. The quantitative analysis of plant growth (Vol. 1). University of California Press, Berkeley, CA, USA, 734 pp.

Falkowski, P.G. \& Raven, J.A. 1997. Aquatic Photosynthesis. Blackwell Science. Malden, MA, USA, 488 pp.

Gagné, J.A., Mann, K.H. \& Chapman, A.R.O. 1982. Seasonal patterns of growth and storage in Laminaria longicruris in relation to differing patterns of availability of nitrogen in the water. Mar. Biol. 69:91-101.

Gaylord, B., Rosman, J.H., Reed, D.C., Koseff, J.R., Fram, J., MacIntyre, S., Arkema, K., McDonald, C., Brzezinski, M.A., Largier, J.L. \& Monismith, S.G. 2007. Spatial patterns of flow and their modification within and around a giant kelp forest. Limnol. Oceanogr. 52:1838-52.

Gerard, V.A. \& Mann, K.H. 1979. Growth and production of Laminaria longicruris (Phaeophyta) populations exposed to different intensities of water movement. J. Phycol. $15: 33-41$.

Gerard, V.A. 1987. Hydrodynamic streamlining of Laminaria saccharina Lamour. in response to mechanical stress. J. Exp. Mar. Biol. Ecol. 107:237-44.

Grabemann, I. \& Weisse, R. 2008. Climate change impact on extreme wave conditions in the North Sea: an ensemble study. Ocean Dyn. 58:199-212.

Graham, M.H. 2004. Effects of local deforestation on the diversity and structure of southern 
California giant kelp forest food webs. Ecosystems 7:341-57.

Hanisak, M.D. 1983. The nitrogen relationships of marine macroalgae. In Carpenter, E.J. \& Capone, D.G. [Eds.] Nitrogen in the Marine Environment. Academic Press, New York, pp. 699730 .

Hepburn, C.D., Holborow, J.D., Wing, S.R., Frew, R.D. \& Hurd, C.L. 2007. Exposure to waves enhances the growth rate and nitrogen status of the giant kelp Macrocystis pyrifera. Mar. Ecol. Prog. Ser. 339:99-108.

Hurd, C.L. 2000. Water motion, marine macroalgal physiology, and production. J. Phycol. $36: 453-72$.

Hurd, C.L., Harrison, P.J., Bischof, K. \& Lobban, C.S. 2014. Seaweed ecology and physiology. Cambridge University Press, Cambridge, MA, USA, 384 pp.

Hurd, C.L. 2017. Shaken and stirred: the fundamental role of water motion in resource acquisition and seaweed productivity. Pers. Phycol. 4:73-81.

Kraemer, G.P. \& Chapman, D.J. 1991. Effects of tensile force and nutrient availability on carbon uptake and cell wall synthesis in blades of juvenile Egregia menziesii (Turn.) Aresch. (Phaeophyta). J. Exp. Mar. Biol. Ecol. 149:267-77.

Kregting, L.T., Hurd, C.L., Pilditch, C.A. \& Stevens, C.L. 2008. The relative importance of water motion on nitrogen uptake by the subtidal macroalga Adamsiella chauvinii (Rhodophyta) in winter and summer. J. Phycol. 44:320-30.

Kregting, L., Blight, A., Elsäßer, B. \& Savidge, G. 2013. The influence of water motion on the growth rate of the kelp Laminaria hyperborea. J. Exp. Mar. Biol. Ecol. 448:337-45.

Kregting, L. \& Elsäßer, B. 2014. A hydrodynamic modelling framework for strangford lough part 1: tidal model. J. Mar. Sci. Eng. 2:46-65. 
Kregting, L., Blight, A.J., Elsäßer, B. \& Savidge, G. 2016. The influence of water motion on the growth rate of the kelp Laminaria digitata. J. Exp. Mar. Biol. Ecol. 478:86-95.

Krumhansl, K.A., Demes, K.W., Carrington, E. \& Harley, C.D. 2015. Divergent growth strategies between red algae and kelps influence biomechanical properties. Am. J. Bot. 102:1938-44.

Mann KH. 1972. Ecological energetics of the seaweed zone in a marine bay on the Atlantic Coast of Canada. I. Zonation and biomass of seaweeds. Mar. Biol. 12:1-10.

Martone, P.T. 2007. Kelp versus coralline: Cellular basis for mechanical strength in the wave-swept seaweed Calliarthron (Corallinaceae, Rhodophyta). J. Phycol. 43:882-91.

Mass, T., Genin, A., Shavit, U., Grinstein, M. \& Tchernov, D. 2010. Flow enhances photosynthesis in marine benthic autotrophs by increasing the efflux of oxygen from the organism to the water. Proc. Natl. Acad. Sci. USA 107:2527-31.

Niklas, K.J. \& Enquist, B.J. 2001. Invariant scaling relationships for interspecific plant biomass production rates and body size. Proc. Natl. Acad. Sci. USA 98:2922-27.

R Core Team. 2018. R: A language and environment for statistical computing. R Foundation for Statistical Computing, Vienna, Austria.

Reed, D.C., Rassweiler, A., Carr, M.H., Cavanaugh, K.C., Malone, D.P. \& Siegel, D.A. 2011. Wave disturbance overwhelms top-down and bottom-up control of primary production in California kelp forests. Ecology 92:2108-16.

Rhein, M., Rintoul, S.R., Aoki, S., Campos, E., Chambers, D., Feely, R.A., Gulev, S., Johnson, G.C., Josey, S.A., Kostianoy, A. \& Mauritzen, C., 2013. Observations: Ocean, chapter 3. Climate Change. 
Sakanishi, Y., Kasai, H. \& Tanaka, J. 2017. Trade-off relationship between productivity and thallus toughness in Laminariales (Phaeophyceae). Phycol. Res. 65:103-10.

Schaffelke, B. \& Luning, K. 1994. A circannual rhythm controls seasonal growth in the kelps Laminaria hyperborea and L. digitata from Helgoland (North Sea). Eur. J. Phycol. 29:49-56.

Smale, D.A., Burrows, M.T., Evans, A.J., King, N., Sayer, M.D., Yunnie, A.L. \& Moore, P.J. 2016. Linking environmental variables with regional-scale variability in ecological structure and standing stock of carbon within UK kelp forests. Mar. Ecol. Prog. Ser. 542:79-95.

Sousa, W.P. 1985. Disturbance and patch dynamics on rocky intertidal shores. In Pickett, S.T.A. \& White, P.S. [Eds.] The ecology of natural disturbance and patch dynamics, Academic Press, Cambridge, MA, USA, 472 pp.

Stephens, T.A. \& Hepburn, C.D. 2016. A kelp with integrity: Macrocystis pyrifera prioritises tissue maintenance in response to nitrogen fertilisation. Oecologia 182:71-84.

Stevens, C.L., Hurd, C.L. \& Smith, M.J. 2002. Field measurement of the dynamics of the bull kelp Durvillaea antarctica (Chamisso) heriot. J. Exp. Mar. Biol. Ecol. 269:147-71.

Wheeler, W.N. 1980. Effect of boundary layer transport on the fixation of carbon by the giant kelp Macrocystis pyrifera. Mar. Biol. 56:103-10.

Table 1. Geographical locations for each study site; low current and low wave (LCLW), high current and low wave (HCLW), high wave and low current (HWLC) and the deployment locations of the Acoustic Doppler Current Profiler (ADCP) devices; Aquadopp 1, Aquadopp 2 and Acoustic Wave and Current Profiler (AWAC). Average significant wave heights and current velocity associated with each ADCP and replicate sites. (Full details of devices can be found in Table 2).

$\begin{array}{llll}\text { Classification/ADCP Site } & \text { Latitude and Longitude } & \text { Hydrodynamic }\end{array}$
condition 


\begin{tabular}{ccccc}
\hline & & & Wave & Current \\
\hline LCLW & Killyleagh 1 & $54.401^{\circ} \mathrm{N}, 5.640^{\circ} \mathrm{W}$ & Low & Low \\
LCLW & Killyleagh 2 & $54.404^{\circ} \mathrm{N}, 5.636^{\circ} \mathrm{W}$ & Low & Low \\
LCLW & Killyleagh 3 & $54.406^{\circ} \mathrm{N}, 5.641^{\circ} \mathrm{W}$ & Low & Low \\
Aquadopp 1 & Killyleagh & $54.403^{\circ} \mathrm{N}, 5.639^{\circ} \mathrm{W}$ & $0.15 \mathrm{~m}$ & $0.12 \mathrm{~m} \cdot \mathrm{s}^{-1}$ \\
\hline HCLW & Cloughy Rock 1 & $54.3568^{\circ} \mathrm{N}, 5.5442^{\circ} \mathrm{W}$ & Low & High \\
HCLW & Cloughy Rock 2 & $54.3615^{\circ} \mathrm{N}, 5.5461^{\circ} \mathrm{W}$ & Low & High \\
HCLW & Gowland Rock & $54.3595^{\circ} \mathrm{N}, 5.5383^{\circ} \mathrm{W}$ & Low & High \\
Aquadopp 2 & Cloughy Rock 1 & $54.3568^{\circ} \mathrm{N}, 5.5442^{\circ} \mathrm{W}$ & $0.09 \mathrm{~m}$ & $0.34 \mathrm{~m} \cdot \mathrm{s}^{-1}$ \\
\hline HWLC & Killard 1 & $54.3075^{\circ} \mathrm{N}, 5.5276^{\circ} \mathrm{W}$ & High & Low \\
HWLC & Killard 2 & $54.3036^{\circ} \mathrm{N}, 5.5317^{\circ} \mathrm{W}$ & High & Low \\
HWLC & Kearney 1 & $54.3819^{\circ} \mathrm{N}, 5.4816^{\circ} \mathrm{W}$ & High & Low \\
HWLC & Kearney 2 & $54.3782^{\circ} \mathrm{N}, 5.4868^{\circ} \mathrm{W}$ & High & Low \\
HWLC & Kearney 3 & $54.3701^{\circ} \mathrm{N}, 5.4876^{\circ} \mathrm{W}$ & High & Low \\
\hline & $54.3683^{\circ} \mathrm{N}, 5.4769^{\circ} \mathrm{W}$ & $0.79 \mathrm{~m}$ & $0.08 \mathrm{~m} \cdot \mathrm{s}^{-1}$ \\
\hline & & & \\
\hline
\end{tabular}

Table 2. Sampling configuration for each ADCP instrument.

$\begin{array}{cccc}\text { Measurement } & \text { AWAC } & \begin{array}{c}\text { Aquadopp 1 } \\ 2 \mathrm{MHz}\end{array} & \begin{array}{c}\text { Aquadopp 2 } \\ 1 \mathrm{MHz}\end{array} \\ \text { Profile Interval (s) } & 900 & 900 & 900 \\ \text { Average interval (s) } & 120 & 120 & 120 \\ \text { Number of cells } & 20 & 30 & 30 \\ \text { Cell size (m) } & 1 & 0.30 & 0.30 \\ \text { Blanking distance (m) } & 0.50 & 0.20 & 0.20\end{array}$


Wave - interval (s)

Wave - sampling rate $(\mathrm{Hz})$

Wave - cell size (m)

Number of samples

Coordinate system

Salinity

Firmware version
3600

7200

7200

1

2

2

1

1

1024

2048

2048

ENU

ENU

ENU

35

35

35

$1.19 \mathrm{AST}$

3.40

1.17 
Table 3. Model comparison of LMMs on the transformed meristematic relative growth rate (MRGR). Akaike information criterion (AIC), estimates the fit of each statistical model. Regression coefficients are relative to the reference site (LCLW) and are on the transformed scale (square-root transformation). Regression coefficient estimates represent a $28 \%$ decrease and a $17 \%$ increase in RGR for wave-dominated and current-dominated areas respectively.

$\begin{array}{lllll}\text { Fixed Effects } & \text { Estimate } & \text { Std. Error } & T & P\end{array}$

\section{Final linear mixed model $(\mathrm{AIC}=35.74)$}

High wave

$-0.25$

0.044

$-5.83$

$<0.01^{*}$

High current

0.14

0.048

2.81

$0.02 *$

\section{Removal of nitrate $(\mathrm{AIC}=\mathbf{4 2 . 9 6})$}

Phosphate

$-0.018$

0.02

$-0.88$

0.38

High wave

$$
-0.246
$$

0.047

$-5.292$

$<0.01^{*}$

High current

0.133

0.05

2.639

$0.03 *$

\section{Removal of phosphate $(\mathrm{AIC}=\mathbf{4 3 . 2 5})$}

Nitrate

High wave

High current

0.002

$-0.255$

0.134

\section{Initial linear mixed model $(\mathrm{AIC}=\mathbf{5 0 . 3 6})$}

0.006

$-0.019$

$-0.246$

0.131

High current

* Significant differences between effect and LCLW

Phosphate

0.02

High wave

0.047

$\begin{array}{lll}0.025 & 0.065 & 0.948\end{array}$

0.044

$-5.765$

$<0.01$ *

2.731

$0.03 *$

$-0.911$

0.363

$-5.245$

$<0.01^{*}$

This article is protected by copyright. All rights reserved 
Table 4. Model comparison of LMMs on the transformed blade relative growth rate (BRGR). Akaike information criterion (AIC), estimates the fit of each statistical model. Regression coefficients are relative to the reference site (LCLW) and are on the transformed scale (square-root transformation). Regression coefficients represent a significant $30 \%$ decrease and a nonsignificant 5\% decrease in RGR for wave-dominated and current-dominated areas respectively.

\begin{tabular}{lllll}
\hline Fixed Effects & Estimate & Std. Error & $T$ & $P$
\end{tabular}

\section{Final linear mixed model $(\mathrm{AIC}=\mathbf{4 1 . 1 8})$}

$\begin{array}{lllll}\text { High wave } & -0.17 & 0.05 & -3.37 & <0.01^{*}\end{array}$

$\begin{array}{lllll}\text { High current } & -0.02 & 0.05 & -0.432 & 0.68\end{array}$

\section{Initial linear mixed model $(\mathrm{AIC}=\mathbf{5 6 . 0 3})$}

Phosphate

$$
0.014
$$

0.022

0.652

0.515

Nitrate

$-0.003$

0.027

$-0.121$

0.904

High wave

$-0.17$

0.051

$-3.338$

$<0.01^{*}$

High current

$-0.02$

0.057

$-0.370$

0.72

* Significant differences between effect and LCLW 
Figure 1 Strangford Lough, Northern Ireland $\left(54.4830^{\circ} \mathrm{N}, 5.5830^{\circ} \mathrm{W}\right)$ showing the location of study sites and deployment sites for Acoustic Doppler Current Profilers (ADCPs); Aquadopp 1, Aquadopp 2 and the Acoustic Wave and Current Profiler (AWAC). Killyleagh 1, 2 \& 3 = Low Current/Low Wave (LCLW), Cloughy Rock 1, 2 \& Gowland Rock = High Current/Low Wave (HCLW) and Killard 1, 2, Kearney 1, 2 \& 3 = High Wave/Low Current (HWLC). GPS coordinates of each site can be found in Table 1.

Figure 2 Significant wave height $(\mathrm{Hm} 0)$ and current velocity $\left(\mathrm{m} \cdot \mathrm{s}^{-1}\right)$ observed at all three hydrodynamic conditions during the winter 2017 sampling period, Kearney (A \& B) classed as a High Wave \& Low Current site, Cloughy Rock (C \& D) classed as a High Current \& Low Wave site and Killyleagh (E \& F) as a Low Current \& Low Wave site.

Figure 3 Meristematic relative growth rate of Laminaria digitata blade ( $\mathrm{d}^{-1}$; untransformed) across three hydrodynamic conditions; Low Current/Low Wave (LCLW), High Wave/Low Current (HWLC) and High Current/Low Wave (HCLW) in winter 2016, summer 2016 and winter 2017 $\left(\mathrm{n}=15-20\right.$ individuals per site). Boxes show interquartile range $\left(25^{\text {th }}-75^{\text {th }}\right.$ percentile $)$ with whiskers indicating $10^{\text {th }}$ and $90^{\text {th }}$ percentiles (outliers marked individually).

Figure 4 Blade relative growth rate of Laminaria digitata $\left(\mathrm{d}^{-1}\right.$; untransformed) across three hydrodynamic conditions; Low Current/Low Wave (LCLW), High Wave/Low Current (HWLC) and High Current/Low Wave (HCLW) in winter 2016, summer 2016 and winter 2017 (n=15-20 individuals per site). Boxes show interquartile range $\left(25^{\text {th }}-75^{\text {th }}\right.$ percentile $)$ with whiskers indicating $10^{\text {th }}$ and $90^{\text {th }}$ percentiles (outliers marked individually). 


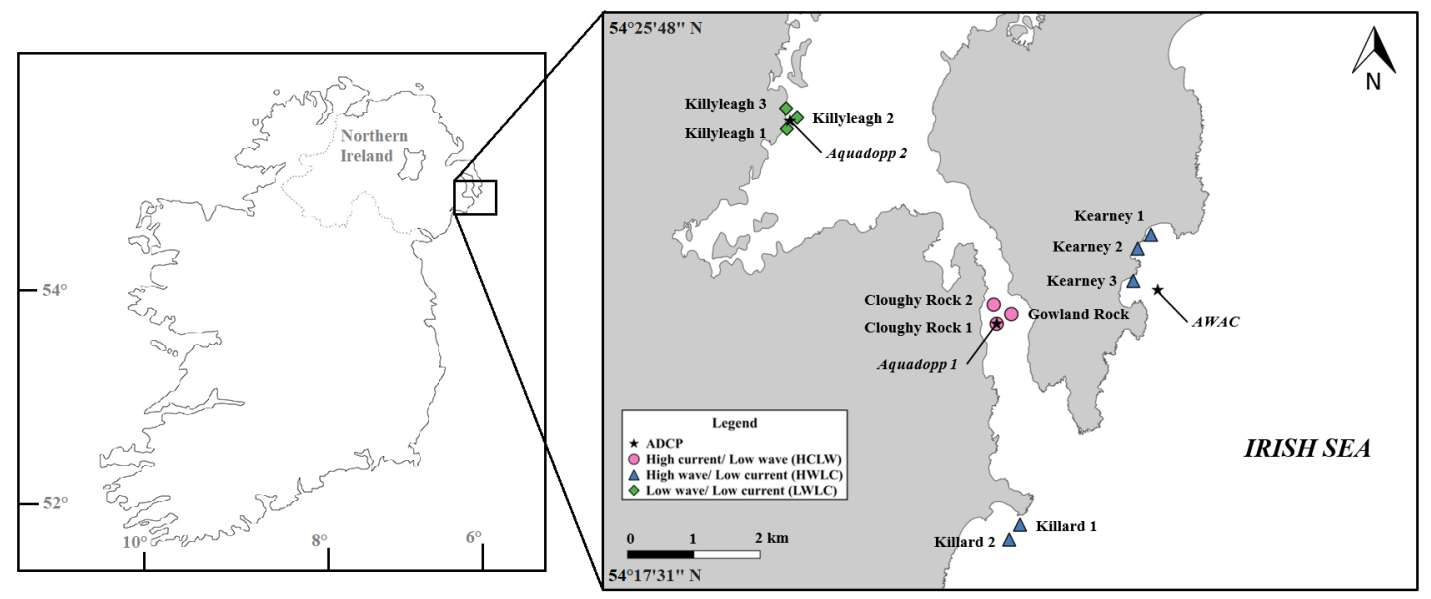

jpy_12943-18-194_f1.png 


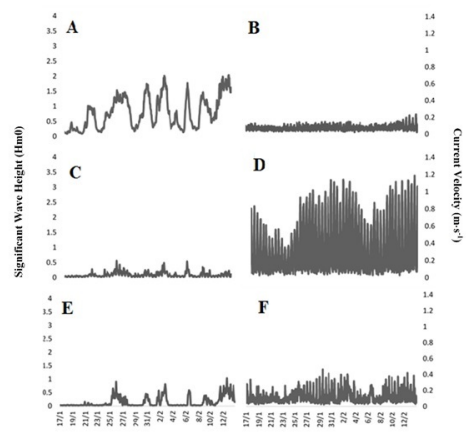

jpy_12943-18-194_f2.tif 


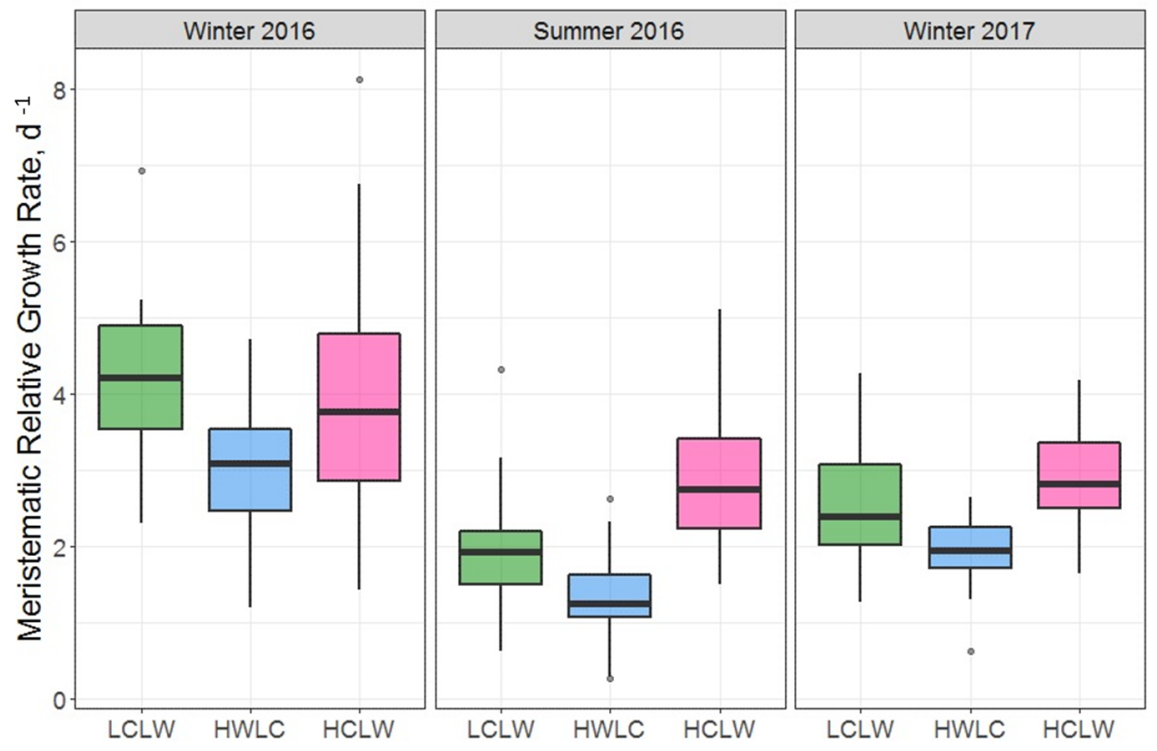

jpy_12943-18-194_f3.tif 

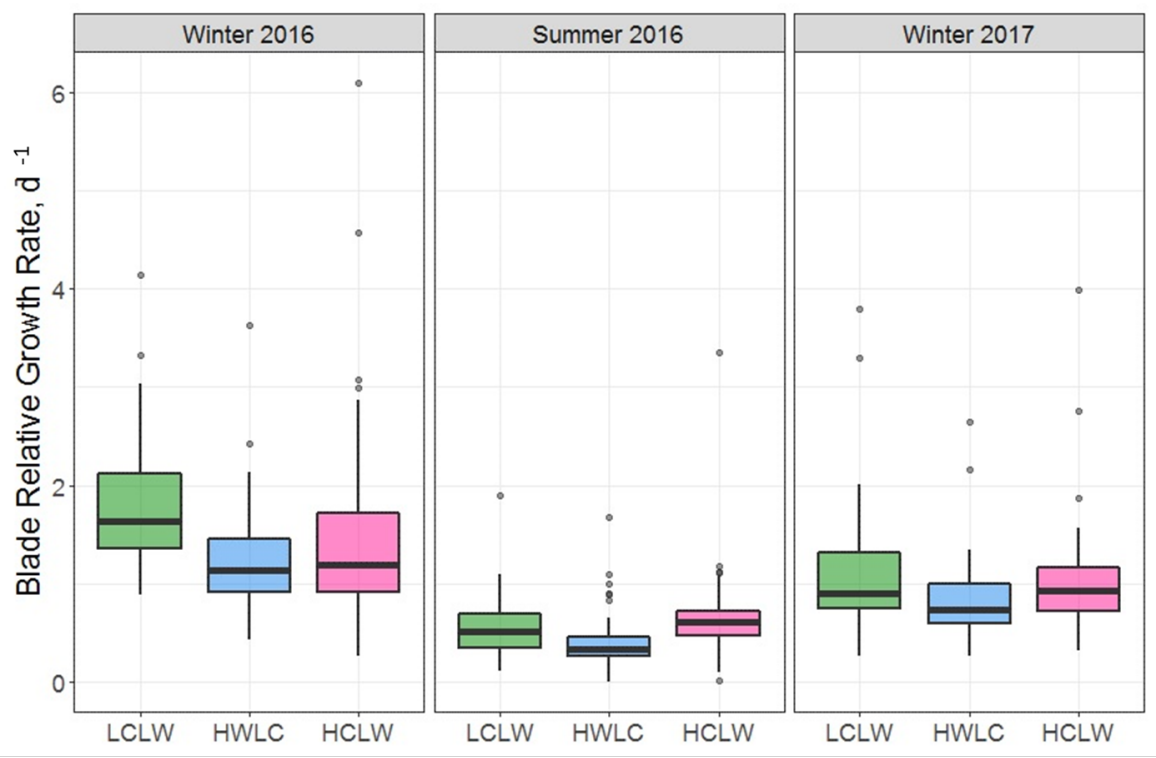

jpy_12943-18-194_f4.tif

This article is protected by copyright. All rights reserved 